\title{
CONTROL OF THRIPS TABACI (LINDMAN) (HOMOPTERA: THRIPDIDAE) UNDER FIVE CHECKED DIFFERENT LEVELS OF FERTILIZER GLADIOLUS SP.(IRIDACEAE) \\ Azer,W.Z. ${ }^{1}$; H.M. Sobhey ${ }^{1}$, A.M.A.Mansour ${ }^{2}$ and Enas A.Abdelatif ${ }^{2}$ \\ ${ }^{1}$ Institute of African Research and Studies, Cairo Univ. \\ ${ }^{2}$ Plant protection Research Institute, A.R.C.Dokki,Giza.
}

\begin{abstract}
The present investigation was carried out at the ornamental flower farm in Abu Galeb village, Giza governorate throughout two successive seasons (2013 and 2014). The experiment studied the effect of four different pesticides (Ashok, Bovaria, Mlathion and Actara) under five different fertilizer levels on the population density of the onion thrips Thrips tabaci (lind.) infested Gladiolus sp.(Iridaceae). Obtained results during two seasons indicated that, the most efficient control agents after general mean of 14 days of spraying was Ashok for non fertilizer $(0,0,0)$ the reduction percentages was 1 \% of $\mathrm{T}$. tabaci on 2013 season and $\vee \uparrow \%$ on 2014 season, respectively. on the other hand, the least potent was Mlathion for non fertilizer $(0,0,0)$ the reduction percentages was $\leqslant \wedge \%$ of T.tabaci on 2013 season and $\leqslant r \%$ on 2014 season, respectively. After general mean of 14 days of spraying.
\end{abstract}

\section{INTRODUCTION}

Gladiolus is a spike-type flower that is gaining popularity with small scale growers for both local and export markets, gladiolus is popular to consumers and florist because it has many spike forms, colours and cooler combinations, an advantage in every floral arrangement gladiolus has been an all time favourite for long in the cut-flower industry and one of its' big advantage is its' ability to tolerate heat as long as air humidity and soil moisture are at an optimum. Anon (2003).The gladiolus, Gladiolus grandiflorus are a complex of at least 11 species and are grown from corms propagated from cormels (daughter corms), and grown throughout Africa and Mediterranean regions with the greatest concentration in South Africa. Laurence (2010).

Soil fertility management may also affect thrips infestation and damage. According to one source, a lack of adequate soil calcium may invite higher populations of thrips. Another writer suggests that nutritional balance can reduce thrips attack. High nitrate levels will invite thrips, and the effects of excessive nitrate are compounded by shortages of potassium, sulfur, boron, and manganese. Foliar applications of soluble calcium and kelp will balance the excess nitrogen. These nutrient levels can be monitored on a weekly basis, using plant tissue analysis, to make accurate adjustments. Mahr et al. (2001).

Soils with high organic matter and active soil biology generally exhibit good soil fertility. Crops grown in such soils generally exhibit lower abundance of several insect herbivores, reductions that maybe attributed to a 
lower nitrogen content in organically farmed crops. On the other hand, farming practices, such as excessive use of inorganic fertilizers, can cause nutrient imbalances and lower pest resistance. Altieri and Nicholls(2003).

Pathogen can be used to suppress thrips. Populations. Adult thrips appears to be most susceptible to fungi because they generally occur in flowers where humidity is higher and conditions more favourable for infection. The higher humidity in the flowers increases the potential for the fungus to speculate and infect additional thrips. Beauveria bassiana suppresses thrips as well as currently registered insecticides does . Loung(2008)

The conventional insecticides sumithion and non conventional insecticides svefes and biofly exhibited a high efficiency against the onion thrips T. tabaci population with highest reduction percentage. Also, the micro-element Born was the highest percentage of reduction followed by Manganase(Awadalla et al2011).

All three insecticides (Acephate, Bifenthrin, and Spinosad) were effective in keeping the thrips infestation below a predetermined level, five thrips per plant, but Bifenthrin required the most number of applications to do so. For chrysanthemum, a fast-growing crop and heavy utilize of fertilizer, fertilization influenced not only the population growth of pest insects but also plant production time. Chau et al.(2005).

\section{MATERIALS AND METHODS}

The present study was carried in ornamental farm in Abu Galb village at Giza Government, Egypt; to study the insects infected certain cut flowering plants in tow successive years 2013 and 2014. The soil was moderately well drained with sandy loam texture in all experiments. Experimental area was $240 \mathrm{~m} 2$; the experimental area was divided into five equal plots, according to fertilization trials. The field was properly prepared, weeds and stubbles were cleared, ploughed, harrowing, levelling, open the furrows and ridges as $50 \mathrm{~cm}$ per spacing Irrigation channels were made a day prior to the planting. The plugging to a depth $30 \mathrm{~cm}$.Application of composed (plants remains) $40 \mathrm{~kg}$ per the planting area $(240 \mathrm{~m} 2)$ after land preparing. Fertilization was ammonium nitrate $(\mathrm{N})$ which contain $30-33 \%$ N2., mono calcium super phosphate $(p)$ which contain $15 \%$ P2O5, potassium sulphate $(\mathrm{K})$ which contain $48 \% \mathrm{~K} 2 \mathrm{O}$ and Kristalon ,N :P: K: 20:20:20.. The experiment was laid out under randomized complete block design. Every plot was divided into 5 suplots for pesticides treatment and control. Everyone was 3 rows. According to ( William and Grant 2011) for accounting units of fertilizer, the nitrogen, phosphorus and potassium treatments tried in this trail were:(T0):control (untreated),(T1): kristalon 20:20:20 units (63.56kg/fed.),(T2): Kristalon plus nitrogen $25: 20: 20$ units $(63.56+6.36 \mathrm{~kg} / \mathrm{fed}$.) , (T3) :kristalon plus phosphorus 20:25:20 units $(63.56+14 \mathrm{~kg} / \mathrm{fed}$.). (T4) : kristalon plus potassium 20:20:25 units $(63.56+4.38 \mathrm{~kg} / \mathrm{fed}$.) , All five fertilizers treatments were applied at the time of sowing as top dressings, The insecticides listed blow (table 1).Applying the insecticides was in the early morning, using the ground motor, before spraying and 3days.,7days and 14days after application of insecticides 
by counting thrips population mean number of insects/ plant in 3 plants, ,selected randomly in each treated and un treated plot. The tested pest was the insecticides used and their common, trade and chemical name Chauha and Sharma (2004). The rates of application of investigated insecticides are shown in table (1). Target pests the infested Gladiolus sp.,A few flowers collected periodically during the experimentation period and placed in a small container with $70 \%$ alcohol. The container can be shaken to dislodge the thrips, which can then be examined under a microscope to identify the spescies. The samples of onion thrips, Thrips tabaci (lind.) were identified by Insect Classification Dept.,Plant Protection Research Institute, Dokki,Giza,Egypt. The number of thrips in the flowers determined by picking the flower and placing it in on a white board. Gently tear open the flower so that the thrips will emerge onto the board where the adults and larvae can be readily distinguished and counted.

Table(1):Treatment procedures:

\begin{tabular}{|c|c|c|c|c|}
\hline No & common name & Trade name & chemical structure & $\begin{array}{c}\text { Rate } / 100 \mathrm{~L} . \\
\text { water. }\end{array}$ \\
\hline 1 & Malathion & Mlathion & Dimethoxy phosphorothiol & $1.5 \mathrm{~L}$. \\
\hline 2 & Ashok & Neem & Azatin(margosan-o) & $750 \mathrm{~cm}^{3}$. \\
\hline 3 & Bovaria $50 \% E C$ & Bovaria $50 \% E C$ & $\begin{array}{c}\text { Fungi of } \\
\text { B.bassiana(seb8661)strain }\end{array}$ & $400 \mathrm{gm}$. \\
\hline 4 & Actara & Actara & Thiamethoxam & $20 \mathrm{gm}$. \\
\hline
\end{tabular}

Statistical Analysis:

The statistical analysis was carried out by using ANOVA analysis in SAS program (2004).

The reduction percentage, ( $\mathrm{R} \%$ percentage) of population reduction was carried out by Henderson and Telton equation(1955) :

Percentage of reduction = 100 [1-(Ta X Cb / Tb X Ca)] where:-

Ta: Post-treatment count in treated plod

Tb: Pre-treatment count in treated plot

Ca: Untreated count before treatment in control plot

$\mathrm{Cb}$ : Untreated count after treatment in control plot

\section{RESULTS AND DISSECTION}

\section{1-Effect of different rates of fertilizers on T.tabaci infesting Gladiolus} sp.:

Field treatments of the infested gladiolus plants by T.tabaci revealed that the number of alive thrips increased in the 25-20-20 rate of fertilizer while it decreased with the most tested rates. The population density of T.tabaci at sampling sites undertaken in the field planted gladiolus during different days $(0,3,7$ and 14 day) presented for 2013 season in (table 2$)$,.population of thrips was different among the rate of fertilizer, highest number of thrips was found 
on $25-20-20$ rate of fertilizer among all sampling in season 2013 . The tested rates of fertilizer could be arranged in ascending order according to general means number of alive thrips as following 25-20-20,20-25-20,20-20-25,20-2020 and $0-0-0$.The corresponding values of general mean were ( 37.2,29.3,29.2,28.7 and 24.7) respectively. For 2014 season (Table 3) The tested rates of fertilizer could be arranged in ascending order according general means number of alive thrips as following 25-20-20,20-20-20,20-25$20,20-20-20$ and $0-0-0$. The corresponding values of general mean were ( $61.8,53.2,51.2,50.75$ and 45.9$)$ respectively. These results are agree with Altieri and Nicholls (2003) Who found reductions in thrips population may be attributed to a lower nitrogen content in organically farmed crops.

Table(2): Evaluation of different compounds against Thrips tabaci on fertilizing Gladiolus sp. during seasons 2013

\begin{tabular}{|c|c|c|c|c|c|c|c|c|c|c|c|c|c|}
\hline \multirow{3}{*}{ Treatment } & \multicolumn{11}{|c|}{ Fertilizing rate } & \multirow{3}{*}{$\begin{array}{c}\text { G. } \\
\text { mean }\end{array}$} & \multirow{3}{*}{$\begin{array}{l}\text { residual } \\
\text { effect }\end{array}$} \\
\hline & & \multicolumn{2}{|c|}{$25-20-20$} & \multicolumn{2}{|c|}{$20-25-20$} & \multicolumn{2}{|r|}{$\left|\begin{array}{c}20- \\
20-25\end{array}\right|$} & & $\begin{array}{l}20- \\
20- \\
20\end{array}$ & & $0-0-0$ & & \\
\hline & & mean & $\mathbf{R} \%$ & mean & $\mathbf{R} \%$ & mean & $\mathbf{R} \%$ & mean & $\mathbf{R} \%$ & Mean & $\mathbf{R} \%$ & & \\
\hline \multirow{4}{*}{ Ashok } & pre & 78 & -- & 60 & -- & 62 & -- & 63 & -- & 53 & -- & 63.2 & -- \\
\hline & 3D. & 27 & $55 \%$ & 17 & $55 \%$ & 18 & $51 \%$ & 14 & $62 \%$ & 16 & $60 \%$ & 18.4 & $57 \%$ \\
\hline & 7D. & 16 & $65 \%$ & 13 & $57 \%$ & 14 & $64 \%$ & 13 & $64 \%$ & 12 & $62 \%$ & 13.6 & $62 \%$ \\
\hline & 14D. & 11 & $71 \%$ & 9 & $73 \%$ & 10 & $67 \%$ & 7 & $71 \%$ & 8 & $68 \%$ & 9 & $70 \%$ \\
\hline \multirow{4}{*}{ Bovaria } & pre & 74 & -- & 58 & -- & 54 & -- & 59 & -- & 49 & -- & 58.8 & -- \\
\hline & 3D. & 23 & $59 \%$ & 33 & $53 \%$ & 16 & $52 \%$ & 17 & $55 \%$ & 22 & $40 \%$ & 22.2 & $50 \%$ \\
\hline & \begin{tabular}{|l|} 
7D. \\
\end{tabular} & 12 & $72 \%$ & 11 & $62 \%$ & 10 & $72 \%$ & 10 & $66 \%$ & 16 & $46 \%$ & 11.8 & $64 \%$ \\
\hline & 14D. & 10 & $72 \%$ & 8 & $75 \%$ & 9 & $68 \%$ & 8 & $65 \%$ & 10 & $57 \%$ & 9 & $67 \%$ \\
\hline \multirow{4}{*}{ Actara } & pre & 73 & -- & 60 & -- & 58 & -- & 61 & -- & 45 & -- & 59.4 & -- \\
\hline & 3D. & 36 & $35 \%$ & 19 & $50 \%$ & 20 & $42 \%$ & 21 & $44 \%$ & 20 & $41 \%$ & 23.2 & $42 \%$ \\
\hline & \begin{tabular}{|l|} 
7D. \\
\end{tabular} & 14 & $67 \%$ & 12 & $61 \%$ & 15 & $52 \%$ & 15 & $49 \%$ & 14 & $49 \%$ & 14 & $56 \%$ \\
\hline & 14D. & 16 & $55 \%$ & 11 & $67 \%$ & 13 & $54 \%$ & 10 & $57 \%$ & 9 & $58 \%$ & 11.8 & $58 \%$ \\
\hline \multirow{4}{*}{ Mlathion } & pre & 75 & -- & 58 & -- & 63 & -- & 60 & -- & 52 & -- & 61.6 & -- \\
\hline & 3D. & 36 & $36 \%$ & 29 & $22 \%$ & 28 & $25 \%$ & 26 & $26 \%$ & 23 & $41 \%$ & 28.4 & $30 \%$ \\
\hline & \begin{tabular}{|l|} 
7D. \\
\end{tabular} & 25 & $44 \%$ & 21 & $29 \%$ & 24 & $40 \%$ & 22 & $25 \%$ & 18 & $42 \%$ & 22 & $36 \%$ \\
\hline & 14D. & 19 & $51 \%$ & 16 & $51 \%$ & 15 & $52 \%$ & 16 & $31 \%$ & 13 & $48 \%$ & 15.8 & $47 \%$ \\
\hline \multirow{4}{*}{ Control } & pre & 70 & -- & 55 & -- & 57 & -- & 61 & -- & 40.3 & -- & 56.6 & -- \\
\hline & 3D. & 53 & -- & 36 & -- & 34 & -- & 38 & -- & 30 & -- & 38.2 & -- \\
\hline & 7D. & 41 & -- & 28 & -- & 36 & -- & 29.6 & -- & 24.3 & -- & 31.7 & -- \\
\hline & 14D. & 34 & -- & 31 & -- & 28 & -- & 23 & -- & 19 & -- & \begin{tabular}{|l|}
23.2 \\
\end{tabular} & -- \\
\hline $\begin{array}{l}\text { General } \\
\text { mean }\end{array}$ & & $37.2 \mathrm{~A}$ & --- & $29.3 \mathrm{~B}$ & -- & $29.2 \mathrm{~B}$ & -- & $28.7 \mathrm{~B}$ & - & $24.7 \mathrm{~B}$ & -- & -- & -- \\
\hline
\end{tabular}

L.S.D.0.05 Treatment : 5.258

L.S.D.0.05 Fertilizer :5.258

Means with the same letter are not significantly different. 
Table(3):Evaluation of different compounds against Thrips tabaci on fertilizing Gladiolus sp. during seasons 2014

\begin{tabular}{|c|c|c|c|c|c|c|c|c|c|c|c|c|c|}
\hline \multirow{3}{*}{ Treatment } & \multicolumn{11}{|c|}{ Fertilizing rate } & \multirow{3}{*}{$\begin{array}{c}\text { G. } \\
\text { mean }\end{array}$} & \multirow{3}{*}{$\begin{array}{c}\text { residual } \\
\text { effect }\end{array}$} \\
\hline & & \multicolumn{2}{|c|}{$25-20-20$} & \multicolumn{2}{|c|}{$20-25-20$} & \multicolumn{2}{|r|}{\begin{tabular}{|c|}
$20-$ \\
$20-25$
\end{tabular}} & \multicolumn{2}{|r|}{\begin{tabular}{|c|}
$20-$ \\
$20-20$
\end{tabular}} & & $0-0-0$ & & \\
\hline & & mean & $\mathbf{R} \%$ & mean & $\mathbf{R} \%$ & mean & $\mathbf{R} \%$ & mean & $\mathbf{R} \%$ & mean & $\mathbf{R} \%$ & & \\
\hline \multirow{4}{*}{ Ashok } & pre & 90 & -- & 81 & -- & 70 & -- & 69 & -- & 67 & -- & 75.4 & -- \\
\hline & $3 \mathrm{D}$. & 36 & $61 \%$ & 29 & $64 \%$ & 27 & $68 \%$ & 30 & $62 \%$ & 32 & $58 \%$ & 30.8 & $63 \%$ \\
\hline & 7D. & 29 & $68 \%$ & 21 & $74 \%$ & 18 & $77 \%$ & 22 & $72 \%$ & 28 & $61 \%$ & 23.6 & $69 \%$ \\
\hline & 14D. & 14 & $83 \%$ & 10 & $86 \%$ & 9 & $87 \%$ & 11 & $84 \%$ & 16 & $76 \%$ & 12 & $83 \%$ \\
\hline \multirow{4}{*}{ Bovaria } & pre & 94 & & 85 & & 72 & & 74 & & 71 & & 79.2 & \\
\hline & $3 \mathrm{D}$. & 59 & $36 \%$ & 41 & $39 \%$ & 51 & $40 \%$ & 55 & $32 \%$ & 44 & $43 \%$ & 50 & $38 \%$ \\
\hline & 7D. & 35 & $61 \%$ & 31 & $62 \%$ & 34 & $57 \%$ & 32 & $59 \%$ & 29 & $60 \%$ & 32.2 & $60 \%$ \\
\hline & 14D. & 25 & $71 \%$ & 18 & $76 \%$ & 15 & $79 \%$ & 13 & $81 \%$ & 10 & $85 \%$ & 16.2 & $78 \%$ \\
\hline \multirow{4}{*}{ Actara } & pre & 98 & & 85 & & 72 & & 70 & & 73 & & 79.5 & \\
\hline & $3 \mathrm{D}$. & 52 & $53 \%$ & 45 & $45 \%$ & 48 & $43 \%$ & 47 & $43 \%$ & 41 & $47 \%$ & 46.6 & $46 \%$ \\
\hline & 7D. & 43 & $55 \%$ & 41 & $51 \%$ & 36 & $55 \%$ & 40 & $51 \%$ & 42 & $42 \%$ & 40.4 & $51 \%$ \\
\hline & 14D. & 44 & $51 \%$ & 35 & $54 \%$ & 34 & $53 \%$ & 36 & $50 \%$ & 35 & $55 \%$ & 36.8 & $53 \%$ \\
\hline \multirow{4}{*}{ Mlathion } & pre & 95 & & 83 & & 74 & & 73 & & 71 & & 79.2 & \\
\hline & $3 \mathrm{D}$. & 55 & $40 \%$ & 49 & $39 \%$ & 52 & $40 \%$ & 54 & $34 \%$ & 52 & $33 \%$ & 52.4 & $37 \%$ \\
\hline & 7D. & 53 & $42 \%$ & 46 & $43 \%$ & 48 & $41 \%$ & 52 & $38 \%$ & 44 & $39 \%$ & 48.6 & $39 \%$ \\
\hline & 14D. & 47 & $45 \%$ & 42 & $44 \%$ & 44 & $40 \%$ & 46 & $39 \%$ & 39 & $43 \%$ & 43.6 & $42 \%$ \\
\hline \multirow{4}{*}{ Control } & pre & 95 & -- & 84 & -- & 73 & -- & 69 & -- & 73 & -- & 78.8 & -- \\
\hline & $3 \mathrm{D}$. & 93 & -- & 81 & -- & 85 & -- & 81 & -- & 78 & -- & 83.6 & -- \\
\hline & 7D. & 92 & -- & 82 & -- & 80 & -- & 79 & -- & 73 & -- & 81.2 & -- \\
\hline & 14D. & 87 & -- & 75 & -- & 73 & -- & 71 & -- & $69 \%$ & -- & 61.3 & -- \\
\hline general me & & $61.8 \mathrm{~A}$ & E- & $53.2 \mathrm{~B}$ & F- & $50.75 \mathrm{~B}$ & F- & $51.2 \mathrm{~B}$ & -- & $45.9 \mathrm{~B}$ & -- & -- & -- \\
\hline
\end{tabular}

L.S.D. Treatments: $\mathbf{5 . 8 4 3}$

L.S.D. Fertilizer: 6.235

L.S.D. Time : 5.32

Means with the same letter are not significantly different.

\section{2-Efficacy of different compounds on T.tabaci infesting fertilizing Gladiolus sp.:}

The average pre-treatment numbers of alive thrips were as shown in table (4) for 2013 and table (5) for 2014. Significant difference was obtained between the compounds and pre treatment. According to spraying time we can be noticed that ascending order of a live thrips as following, After 3,7,14 days after treatment the corresponding general means $(26.08,18.82,15.56)$ comparing with 59.9 in 2013, and in 2014 were $(52.68,45.2,33.96)$ comparing with 78.5 in pre treatment. All compounds gave moderate reduction percentage The tested compound could be arranger in ascending order as Mlathion (37\%), Actra (52\%), Ashok (60\%) and Bovaria ( $63 \%$ ) respectively for 2013, and for 2014 were Mlathion (39\%), Actra (50\%), Bovaria $(59 \%)$,Ashok $(72 \%)$, respectively. Concerning the mean residual effects of tested compounds, it is clear that Ashok was highly effective in controlling T.tabaci in fertilizing gladiolus with $(0,0,0)$ which has lowest general mean (24.6) in 2013 , reduction percentage after $3,7,14$ days were $(60 \%, 62 \%, 68 \%)$ respectively and The lowest one was Mlathion (41\%,42\%,48\%).In 2014, also Ashok was highly effective in controlling T.tabaci in fertilizing gladiolus with ( $0,0,0)$ which has lowest general mean (45.9.6), reduction percentage after $3,7,14$ days were $(63 \%, 69 \%, 83 \%)$ respectively and The lowest one was Mlathion $(37 \%, 39 \%, 42 \%)$. The results are agree with those obtained by Shelton et al., (2006) who mentioned that onion thrips is able to acquire some 
resistance to several insecticide families, making chemical treatments ineffective, although this depends on the biology of the pest, the season, environmental factors and number of thrips generations. The insecticides:Thiodan, Confidor, Tracer, Megamos, and Actara were sprayed three times and data were taken at 24 hours, 72 hours, seven days and 10 days intervals. Except Actara, all insecticides were significantly effective against the pest as compared to control Funderburk et al.,(2011) .Maximum cost-benefit ratio was recorded for Confidor (39.45) and the least was recorded for Actara (3.41) treated plots to control T. tabaci on onion crop.

Table(4):Mean and reduction percentage for thrips population after pesticides spray in 2013.

\begin{tabular}{|c|c|c|c|c|c|c|c|c|c|}
\hline \multirow{2}{*}{ Treatments } & \multirow[t]{2}{*}{$\begin{array}{c}\text { Pre- } \\
\text { treatment }\end{array}$} & \multicolumn{2}{|c|}{3 Days } & \multicolumn{2}{|c|}{7 Days } & \multicolumn{2}{|c|}{14 Days } & \multirow[t]{2}{*}{$\begin{array}{c}\text { General } \\
\text { mean }\end{array}$} & \multirow{2}{*}{$\begin{array}{l}\text { Residual } \\
\text { effect }\end{array}$} \\
\hline & & mean & R\% & mean & R\% & mean & R\% & & \\
\hline Bovaria & 58.8 & 22.2 & $50 \%$ & 11.8 & $64 \%$ & 9 & $67 \%$ & 25.45 & $60 \%$ \\
\hline Ashok & 63.2 & 18.4 & $57 \%$ & 13.6 & $62 \%$ & 9 & $70 \%$ & 26.05 & $63 \%$ \\
\hline Mlathion & 61.6 & 28.4 & $30 \%$ & 23 & $33 \%$ & 15.8 & $47 \%$ & 32.2 & $37 \%$ \\
\hline Actara & 59.4 & 23.2 & $42 \%$ & 14 & $56 \%$ & 11.8 & $58 \%$ & 27.1 & $52 \%$ \\
\hline Cntrol & 56.6 & 38.2 & -- & 31.7 & -- & 32.2 & -- & 39.6 & - \\
\hline G. mean & 59.92 & 26.08 & -- & 18.8 & -- & 15.56 & -- & -- & -- \\
\hline
\end{tabular}

Table(5): Mean and reduction percentage for thrips population after pesticides spray in 2014.

\begin{tabular}{|c|c|c|c|c|c|c|c|c|c|}
\hline \multirow{2}{*}{ Treatments } & \multirow[t]{2}{*}{$\begin{array}{c}\text { Pre- } \\
\text { treatment }\end{array}$} & \multicolumn{2}{|c|}{3 Days } & \multicolumn{2}{|c|}{7 Days } & \multicolumn{2}{|c|}{14 Days } & \multirow[t]{2}{*}{$\begin{array}{c}\text { General } \\
\text { mean }\end{array}$} & \multirow{2}{*}{$\begin{array}{c}\text { Residua } \\
\text { effect }\end{array}$} \\
\hline & & mean & $\mathbf{R} \%$ & mean & $\mathbf{R} \%$ & mean & \begin{tabular}{|l|}
$\mathbf{R} \%$ \\
\end{tabular} & & \\
\hline Bovaria & 79.4 & 50 & $38 \%$ & 32.2 & $60 \%$ & 16.2 & $78 \%$ & 44.45 & $59 \%$ \\
\hline Ashok & 75.4 & 30.8 & $63 \%$ & 23.6 & $69 \%$ & 12 & $83 \%$ & 35.45 & $72 \%$ \\
\hline Mlathion & 79.2 & 52.4 & $37 \%$ & 48.6 & $39 \%$ & 43.6 & $42 \%$ & 55.95 & $39 \%$ \\
\hline Actara & 79.8 & 46.6 & $46 \%$ & 40.4 & $51 \%$ & 36.8 & $53 \%$ & 50.9 & $50 \%$ \\
\hline Cntrol & 78.8 & 83.6 & -- & 81.2 & -- & 61.2 & -- & 76.2 & -- \\
\hline G. mean & 78.52 & 52.68 & -- & 45.2 & -- & 33.96 & -- & -- & -- \\
\hline
\end{tabular}

Ullah,(2010). Ahmed and El-Mogy (2011), conclude that it can be use Bio power and Jojoba oil on growing period and Nimbecidine on flowering period in integrated pest management of T.tabaci on onion crop.

Palumbo et al., (2000) reported that, Actara and Avaunt, two new experiential insecticides did not significantly control adults and provided only marginal activity against the larvae when applied alone. Combination of these products with either Lannate or Warrior significantly enhanced control, but usually not greater than that shown from the Lannate or Warrior applied alone. Several botanical products were evaluated (Azadirachtin, Pyrethrins, crop oils and garlic). Unfortunately, none of the botanical products significantly reduced thrips numbers to economically acceptable levels of control. Similar to previous studies, our results suggest that even the most efficacious products appeared to maintain thrips.

Finally, it could be concluded that the treatment of different compounds can be arranged according to its reduction percentage to 
(Ashok,Bovaria,Actara and Mlathion).All compounds gave significant control of T.tabaci, in addition of decreasing the nitrogen fertilizer rate. Mean numbers of T.tabaci on gladiolus plants did not affected by increasing phosphorus and potassium rate with treated compound .Finally, it could be concluded that the treatment of different compounds (Ashok, Bovaria, Mlathion and Actara) under five different fertilizer levels gave significant control of the onion thrips, Thrips tabaci (lind.) infested gladiolus plants ,decrease the nitrogen rate of fertilizer reduced the average number of T.tabaci on gladiolus plants, increase phosphorus and potassium not effect on the number of T.tabaci on gladiolus with the treated compound.

\section{REFERENCES}

Ahmed S.S.;Mohamed M.,E.(2011):Field evaluation of some biological formulations against Thrips tabaci (thysanoptera:Thripidae) in onion.World.App.Sci.J.14(1):51:58

Altieri ,M. A.; and Nicholls, C., I. (2003): Soil fertility management and insect pests: harmonizing soil and plant health in agric systems soil and tillage Research ,72: 203-211.

Anon,M.( 2003) : Cut-flower production and marketing manual. Published by the Horticulture Crops Development Authority, Ministry of Agriculture and the Japan International Co-operation Agency. Nairobi, Kenya. 53p.

Awadalla,s.s;M.E.EINaggar;and Omnia, F.Hamid(2011) Influence of conventional and non conventional insecticides as well as the macroand micro elements on population density onion thrips T. tabaci Lind .J. plant prot. . And path. Mansoura univ.2(2)131-139.

Chauhan,U . and Sharma, K. C. (2004):Insect pests of ornamental cropsidentification and management manual.Dept.of Ento. and $A$ piculture,Unv. of horticulture and Forestry,Nauni-Solan, India.513p.

Chau ,A.; Heinz, K.M.; Davies ,J.F.T.( 2005): Influence of fertilization on Aphis gossypii Glover. and insecticide usage. J. Appl. Entomol. 129 (2): 89-97.

Funderburk J.,Stuart R,phil S.,Steve O.,David S.,Gene M.,Alicia W.,Ozan D.,Greg N., and Norm L.(2011):Managing Thrips in Pepper and Eggplant.ENY-6nt, Florida 58(IN401), one of a series of the Entomo. And Nema. Department,Florida CO.OP.Etension Service, Ins.,of Food and Agric.,sci,Univ., of Florida.http:Wedis.ifas.ufl.edu. Chowetal.

Henderson C.F. and Tiliton W.A (1955):Test with acari cides against the wheat mite,J.Ent.49:157-161.

Laurence ,M.(2010): Species of the GenusThrips(Thysanoptera, Thripidae)from the Afro-tropical Region ,Article,Zootaxa23: 1-24 .

Luong ,L.C.(2008):Investigation into aspects of the biology of tubular black thrips, halothrips victoriensis (Thysanoptera:phlaeothripidae)in south Astralia, M.Sc. Tesis, plant prot. Dep.Unv.of Adelaide,Astralia,96p. 
Mahr,D.L.; Rice S.E.; Colyd R. A.; Sadof C.S. (2001): Biological control of insects and other pests of green house crops.,Univ. Of WisconsinCoop.Ext.Service., 98p.

Palumbo J.; Clayton M.; Francisco J.R.;Andreas A.;luis L.and Lisa C.(2000): Management of Western Flower Thrips in Head Lettuce, part of the University of Arizona College of Agriculture 2000 Vegetable Report, index at http://ag.arizona.edu/pubs/crops/az1177.pp.1-14.

SAS Institute (1994):SAS/STATUsersGuide:statistics.Ver.6.04,4th Edition SAS Intitute Inc., Cary, NC.

Shelton A.M.,Zhao J.Z.,Nault B.A.,Plate J.,Musser F.R.,Larentzakie E.(2006):Patterns of insecticide resistance in onion thrips(Thysanoptera:Thripidae) in onion fiels in New York. J.of Eco.Entomo.,99:1798-1804.

Ullah, F.; Mulk, M.ul.; Farid A.; Saeed M.,Q.;and Sattar Sh.(2010): Population Dynamics and Chemical Control of Onion Thrips (Thrips tabaci, Lindemann) Pakistan J. Zool., vol. 42(4), pp. 401-406.

William,C.W. and Grant,G. (2011):Gladiolus in the Garden,Heirloom Gardening in the South:Yesterday,s plants for Today,s Gardens.TexasA\&M Univ.college Station,537pp.

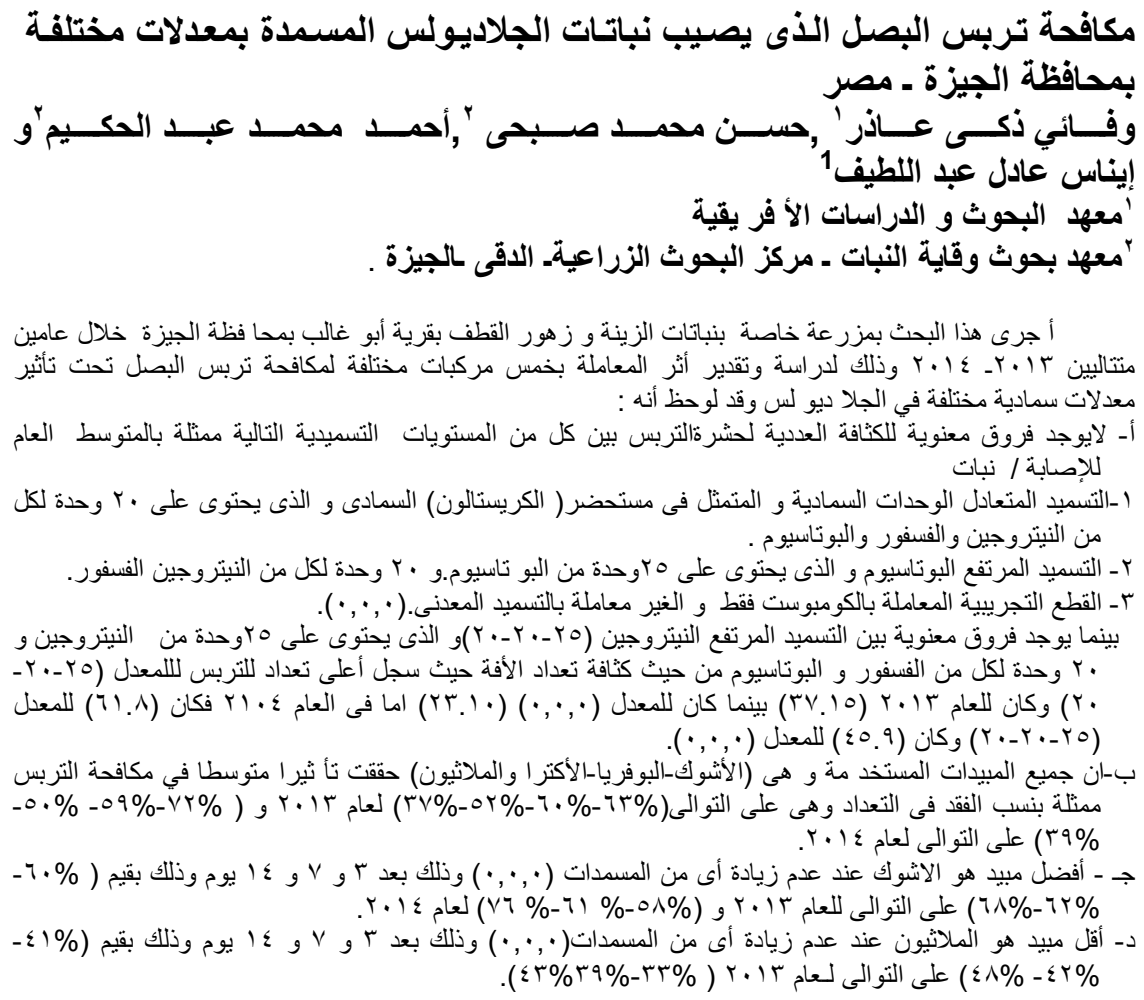


J. Plant Prot. and Path., Mansoura Univ., Vol.6 (12), December, 2015

1761 